\title{
Association between recurrent bacterial vaginosis and Helicobacter pylori infection: a case report
}

\author{
Josh Bleicher, MS, ${ }^{1}$ Colleen K. Stockdale, MD, $\mathrm{MS}^{2}$
}

Keywords: Bacterial vaginosis, Helicobacter pylori, recurrent bacterial vaginosis, recurrent vaginosis

\begin{abstract}
Background: Nearly one in three women in the United States are affected by bacterial vaginosis at some point in their life, with more than fifty percent experiencing recurrent symptoms within 12 months.

Case: A 36 year old G9P2072 with 1 year history of recurrent bacterial vaginosis despite repeated treatments with local and systemic metronidazole, metronidazole suppression, and probiotic therapy had relief of bacterial vaginosis following triple antibiotic therapy for Helicobacter pylori. She remains asymptomatic for both bacterial vaginosis and Helicobacter pylori at 6 month follow up.
\end{abstract}

Discussion: We present a woman with recurrent bacterial vaginosis who had sudden relief of her symptoms following treatment for Helicobacter pylori. While association should not be construed as causation, similar pathogenesis may warrant investigation of $H$ pylori as a potential cause of the complex change in the vaginal flora leading to bacterial vaginosis.

${ }^{1}$ University of lowa Carver College of Medicine, lowa City, lowa

${ }^{2}$ University of lowa Hospitals and Clinics, Department of Obstetrics and Gynecology, lowa City, lowa

\section{Background}

Bacterial vaginosis is the most common cause of vaginal discharge in women of childbearing age, affecting nearly one in three women in the United States. ${ }^{1}$ Bacterial vaginosis causes a wide range of consequences for these women, including a significant emotional burden and an increased risk for both adverse pregnancy outcomes and sexually transmitted infections. Qualitative studies have linked bacterial vaginosis with women feeling dirty, embarrassed, ashamed, self-conscious, and frustrated over a lack of control over their symptoms, leading to negative consequences for themselves and their sexual relationships. ${ }^{2,3}$ These feelings often lead women to perform selfhygienic practices, including douching and use of fragrant soaps, lotions, and powders to try and gain some element of control over their condition. ${ }^{4}$ Unfortunately, many of these practices may contribute to bacterial vaginosis or recurrence of symptoms. The medical consequences of bacterial vaginosis include higher rates of preterm birth in

Please cite this paper as: Bleicher J, Stockdale CK. Association between recurrent bacterial vaginosis and Helicobacter pylori infection: a case report. Proceedings in Obstetrics and Gynecology, 2015;5(2):Article 7 [ 6 p.]. Available from: http://ir.uiowa.edu/pog/ Free full text article.

Corresponding author: Josh Bleicher, University of lowa Carver College of Medicine, lowa City, lowa, joshuableicher@uiowa.edu

Copyright: (c) 2015 Bleicher et al. This is an open-access article distributed under the terms of the Creative Commons Attribution License, which permits unrestricted use, distribution, and reproduction in any medium, provided the original author and source are credited. 
pregnant patients and increased risk of contracting sexually transmitted infections. $^{5}$

\section{Case}

A 36 year old G9P2072 was referred to our tertiary care vulvar vaginal disease clinic for a 1 year history of recurrent bacterial vaginosis treated multiple times with local and systemic metronidazole. She noted resolution of symptoms with each treatment. Besides a new male sex partner and inconsistent condom use, she denied known risk factors for recurrent bacterial vaginosis including multiple sexual partners, sex with women, douching, and use of sex toys. Her past medical history was significant for gastro-esophageal reflux disease, poorly controlled with omeprazole, carpal tunnel syndrome requiring surgery during this time period, and a benign thyroid cyst. Medications included omeprazole, intermittent local and systemic metronidazole for bacterial vaginosis, and intermittent fluconazole for yeast vaginitis following metronidazole therapy. She was asymptomatic at the time of her evaluation including negative vaginal microscopy, $\mathrm{pH}$, and whiff testing. She was advised to follow vulvar skin care guidelines, including avoidance of scented laundry, bathing, and cosmetic items. She also began a trial of probiotics with Kefir.

Despite compliance with these measures, symptoms returned at approximately 2, 6, and 7 months following her initial appointment. On evaluation, she was found to have bacterial vaginosis each time, confirmed by clinical exam, microscopy, $\mathrm{pH}$, and whiff testing. Oral metronidazole and oral fluconazole (prophylaxis) were prescribed for each encounter with reported symptom resolution. Following the $3^{\text {rd }}$ recurrent bacterial vaginosis episode, she received treatment with vaginal and vulvar $1 \%$ gentian violet painting, and was also advised to use vaginal $0.75 \%$ metronidazole vaginal gel prophylactically following intercourse and menses. Despite prophylaxis, she was diagnosed with bacterial vaginosis again 2 weeks and 2 months later.

Ten months following her initial referral to our center, she was diagnosed with Helicobacter pylori $(H$. pylori) following presentation with symptoms of nausea, abdominal pain, and weight loss. Symptoms had worsened acutely; however, she had a long history of gastro-esophageal reflux disease (GERD) poorly controlled with trials of histamine-receptor blockers and omeprazole. When found to be $\mathrm{H}$. pylori antibody positive, she was treated with triple therapy consisting of amoxicillin, clarithromycin, and omeprazole, with confirmed eradication of the bacteria following therapy. Six months following triple therapy, she has remained clinically asymptomatic for bacterial vaginosis with no further prophylaxis or changes to her medical or sexual history.

\section{Discussion}

\section{$\underline{\text { Recurrent bacterial vaginosis }}$}

Bacterial vaginosis occurs when bacterial species such as Gardnerella vaginalis, Atopobium vaginae, and Mobiluncus species replace the normal vaginal flora. ${ }^{6}$ This alteration inhibits lactobacillus from maintaining a vaginal environment conducive to inhibiting 
infection with other bacteria and viruses. The mechanism by which the floral imbalance occurs and the role of sexual activity in the pathogenesis of bacterial vaginosis are not clear, but formation of an epithelial biofilm containing Gardnerella vaginalis appears to play an important role. ${ }^{7,8}$ Bacterial vaginosis has often been associated with sexual activity, with multiple studies demonstrating associations between bacterial vaginosis and new sexual partners, multiple sexual partners, and lack of condom use. ${ }^{9}$ While a significant risk factor, $15 \%$ of women with bacterial vaginosis deny any history of sexual intercourse. ${ }^{1}$ Women who have sex with women are also at increased risk for bacterial vaginosis, with increased number of female partners showing a greater association. ${ }^{10}$ Other risk factors for bacterial vaginosis include taking 4 or more baths in a week, having more than 2 live births, and douching. ${ }^{11}$ Use of oral contraceptive pills appears to be protective.

The Center for Disease Control recommended treatment regimens include oral metronidazole $500 \mathrm{mg}$ twice daily for 7 days, intravaginal $0.75 \%$ metronidazole gel for 5 days, or intravaginal 2\% clindamycin cream for 7 days. ${ }^{12}$ All 3 treatment modalities have been shown to have roughly equivalent effectiveness in curing bacterial vaginosis with similar rates of disease recurrence. ${ }^{13}$ The recurrence rates following all treatments are high. One study following women treated with oral metronidazole found recurrence rates of $23 \%$ at 1 month post-treatment and 68\% at 12 months post-treatment. ${ }^{14}$ Several reasons have been suggested for this high rate of recurrence: failure of normal vaginal flora to take hold post treatment, reinfection through sexual encounters, antibiotic resistance, and the persistence of a polymicrobial vaginal biofilm. For these reasons, condom use is recommended for 3-6 months following treatment. ${ }^{15}$ Evidence showing that treatment of sexual partners and recolonization with lactobacillus supplements is lacking. Prophylactic $0.75 \%$ metronidazole vaginal gel has been shown to prevent recurrence compared to placebo, but over half of women still have recurrent bacterial vaginosis at 28 weeks. ${ }^{16}$ Also, a higher proportion of women treated with prophylactic metronidazole (43.1\%) suffered from vulvovaginal candidiasis in this time period due to the effects of chronic antibiotic therapy.

\section{Link between bacterial vaginosis and} Helicobacter pylori?

Evidence linking $\mathrm{H}$ pylori infection with bacterial vaginosis is lacking; however, several theoretical links exist. $\mathrm{H}$ pylori has been shown to colonize yeast within the vagina and has also been associated with biofilm formation, making it possible that $\mathrm{H}$ pylori is one of many bacterial species seen in biofilms present in bacterial vaginosis leading to treatment failure. $\mathrm{H}$ pylori is commonly found in the stomach and upper gastrointestinal tract, one of the few bacteria able to colonize this acidic environment. ${ }^{17}$ Eslick hypothesized that $\mathrm{H}$ pylori may be able to also colonize the acidic vaginal environment, acting as a reservoir and allowing sexual transmission of the bacteria.

$\mathrm{H}$ pylori isolates have also been found to have an endosymbiotic relationship with Candida albicans, with bacteria 
isolated from within these yeast. ${ }^{18}$ This relationship may allow $\mathrm{H}$ pylori to colonize the vagina. Candida isolated from the vagina has been found to contain $\mathrm{H}$ pylori specific genes, one mechanism for the vertical transmission of $\mathrm{H}$ pylori. ${ }^{19}$ The colonization of the vagina by $\mathrm{H}$ pylori may contribute to the high rates of treatment failure and infection recurrence in some women with bacterial vaginosis.

Many women with recurrent bacterial vaginosis have vaginal epithelium coated in polymicrobial biofilms, primarily composed of Gardnerella vaginosis. $^{20}$ This biofilm is not completely eliminated by recommended treatments, including oral metronidazole. ${ }^{8} \quad$ Antibiotic therapy induces a dormant state in the biofilm, which subsequently reverts to a live state again following treatment, leading to recurrent symptoms of bacterial vaginosis. Recurrent treatment against biofilms also leads to increased bacterial resistance against commonly used antimicrobial agents. A similar effect occurs with $\mathrm{H}$ pylori dominant biofilms in the gastric mucosa, leading to treatment resistance and disease recurrence. ${ }^{21}$

\section{Conclusion}

Improved therapeutic solutions are needed for women who suffer from bacterial vaginosis. Current therapies perform poorly in reducing infection. While the mechanisms behind recurrence of bacterial vaginosis are likely myriad, one potential reason may be coinfection with Helicobacter pylori. The patient in this case report suffered from recurrent bacterial vaginosis despite multiple treatments with oral metronidazole and prophylaxis with metronidazole gel. Six months following eradication of her $\mathrm{H}$ pylori infection, she has remained clinically asymptomatic for bacterial vaginosis.

While association does not imply causation, similar mechanisms of pathogenesis and the prolonged remission experienced following treatment for $\mathrm{H}$ pylori may warrant investigation as a potential contributing etiology to recurrent bacterial vaginosis.

\section{References}

1. Allsworth JE, Peipert JF. Prevalence of bacterial vaginosis: 2001-2004 National Health and Nutrition Examination Survey data. Obstet Gynecol. 2007 Jan;109(1):114-20.

DOI: 10.1097/01.AOG.0000247627.84791.91 PubMed PMID: 17197596.

2. Bilardi JE, Walker S, Temple-Smith $M$, McNair R, Mooney-Somers J, Bellhouse C, Fairley CK, Chen MY, Bradshaw C. The burden of bacterial vaginosis: women's experience of the physical, emotional, sexual and social impact of living with recurrent bacterial vaginosis. PLoS One. 2013 Sep 11;8(9):e74378. doi:10.1371/journal.pone.0074378. PubMed PMID: 24040236.

3. Karasz A, Anderson M. The vaginitis monologues: women's experiences of vaginal complaints in a primary care setting. Soc Sci Med. 2003 Mar;56(5):1013-21.

http://dx.doi.org/10.1016/S02779536(02)00092-8 PubMed PMID: 12593874.

4. Payne SC, Cromer PR, Stanek MK, Palmer AA. Evidence of AfricanAmerican women's frustrations with chronic recurrent bacterial vaginosis. J Am Acad Nurse Pract. 2010 Feb;22(2):101-8. doi: 10.1111/j.17457599.2009.00474.x. PubMed PMID: 20132368. 
5. Martin $\mathrm{HL}$, Richardson BA, Nyange PM, Lavreys L, Hillier SL, Chohan B, Mandaliya K, Ndinya-Achola JO, Bwayo $\mathrm{J}$, Kreiss J. Vaginal lactobacilli, microbial flora, and risk of human immunodeficiency virus type 1 and sexually transmitted disease acquisition. J Infect Dis. 1999 Dec;180(6):1863-8. http://dx.doi.org/10.1086/315127

PubMed PMID: 10558942.

6. Powell AM, Nyirjesy P. Recurrent vulvovaginitis. Best Pract Res Clin Obstet Gynaecol. 2014 Oct;28(7):96776. doi: 10.1016/j.bpobgyn.2014.07.006. Epub 2014 Jul 17. PubMed PMID: 25220102.

7. Alves P, Castro J, Sousa C, Cereija TB, Cerca N. Gardnerella vaginalis outcompetes 29 other bacterial species isolated from patients with bacterial vaginosis, using in an in vitro biofilm formation model. J Infect Dis. 2014 Aug 15;210(4):593-6. doi: 10.1093/infdis/jiu131. Epub 2014 Mar 4. PubMed PMID: 24596283.

8. Swidsinski A, Loening-Baucke V, Swidsinski S, Verstraelen $H$. Polymicrobial Gardnerella biofilm resists repeated intravaginal antiseptic treatment in a subset of women with bacterial vaginosis: a preliminary report. Arch Gynecol Obstet. 2015 Mar;291(3):605-9. doi: 10.1007/s00404014-3484-1. Epub 2014 Sep 23. PubMed PMID: 25245669.

9. Fethers KA, Fairley CK, Hocking JS, Gurrin LC, Bradshaw CS. Sexual risk factors and bacterial vaginosis: a systematic review and meta-analysis. Clin Infect Dis. 2008 Dec 1;47(11):142635. doi: 10.1086/592974. PubMed PMID: 18947329.

10. Bailey JV, Farquhar C, Owen C. Bacterial vaginosis in lesbians and bisexual women. Sex Transm Dis. 2004 Nov;31(11):691-4.

http://dx.doi.org/10.1097/01.olq.0000143 093.70899.68 PubMed PMID: 15502678.
11. Holzman C, Leventhal JM, Qiu H, Jones NM, Wang J; BV Study Group. Factors linked to bacterial vaginosis in nonpregnant women. Am J Public Health. 2001 Oct;91(10):1664-70. http://dx.doi.org/10.2105/AJPH.91.10.16 64 PubMed PMID: 11574333.

12. Workowski KA, Bolan GA; Centers for Disease Control and Prevention. Sexually transmitted diseases treatment guidelines, 2015. MMWR Recomm Rep. 2015 Jun5;64(RR-03):1-137. PubMed PMID: 26042815. http://www.cdc.gov/mmwr/preview/mmw rhtml/rr6403a1.htm

13. Chen JY, Tian H, Beigi RH. Treatment considerations for bacterial vaginosis and the risk of recurrence. J Womens Health (Larchmt). 2009 Dec;18(12):1997-2004. doi: 10.1089/jwh.2008.1088. PubMed PMID: 20044862.

14. Bradshaw CS, Morton AN, Hocking J, Garland SM, Morris MB, Moss LM, Horvath LB, Kuzevska I, Fairley CK. High recurrence rates of bacterial vaginosis over the course of 12 months after oral metronidazole therapy and factors associated with recurrence. J Infect Dis. 2006 Jun 1;193(11):1478-86. Epub $2006 \quad$ Apr 26. http://dx.doi.org/10.1086/503780 PubMed PMID: 16652274.

15. Nyirjesy P. Management of persistent vaginitis. Obstet Gynecol. 2014 Dec;124(6):1135-46. doi: 10.1097/AOG.0000000000000551. PubMed PMID: 25415165.

16. Sobel JD, Ferris D, Schwebke J, Nyirjesy P, Wiesenfeld HC, Peipert J, Soper D, Ohmit SE, Hillier SL. Suppressive antibacterial therapy with $0.75 \%$ metronidazole vaginal gel to prevent recurrent bacterial vaginosis. Am J Obstet Gynecol. 2006 May;194(5):1283-9. Epub 2006 Apr 21. http://dx.doi.org/10.1016/j.ajog.2005.11. 041 PubMed PMID: 16647911. 
17. Eslick GD. Helicobacter pylori infection transmitted sexually via oral-genital contact: a hypothetical model. Sex Transm Infect. 2000 Dec;76(6):489-92. http://dx.doi.org/10.1136/sti.76.6.489

PubMed PMID: 11221134.

18. Siavoshi F, Saniee P. Vacuoles of Candida yeast as a specialized niche for Helicobacter pylori. World J Gastroenterol. $2014 \quad$ May 14;20(18):5263-73. doi: 10.3748/wjg.v20.i18.5263. PubMed PMID: 24833856.

19. Siavoshi F, Taghikhani A, Malekzadeh R, Sarrafnejad A, Kashanian M, Jamal AS, Saniee P, Sadeghi S, Sharifi AH. The role of mother's oral and vaginal yeasts in transmission of Helicobacter pylori to neonates. Arch Iran Med. 2013 May;16(5):288-94. doi: 013165/AIM.009. PubMed PMID: 23641743.

20. Swidsinski A, Mendling W, LoeningBaucke V, Ladhoff A, Swidsinski S, Hale LP, Lochs $H$. Adherent biofilms in bacterial vaginosis. Obstet Gynecol. 2005 Nov;106(5 Pt 1):1013-23. http://dx.doi.org/10.1097/01.AOG.00001 83594.45524.d2 PubMed PMID: 16260520.

21. Cammarota G, Sanguinetti M, Gallo A, Posteraro B. Review article: biofilm formation by Helicobacter pylori as a target for eradication of resistant infection. Aliment Pharmacol Ther. 2012 Aug;36(3):222-30. doi: 10.1111/j.13652036.2012.05165.x. Epub 2012 May 31. PubMed PMID: 22650647. 